\title{
Editorial
}

\section{A propósito del aniversario de la Revista Finanzas y Política Económica}

En el año 2007, la crisis económica mundial se evidenciaba en el desplome del mercado hipotecario del sector financiero en los Estados Unidos, en el año siguiente, esta manifestaba sus primeras consecuencias con la caída de las inversiones, las cuales afectarían directamente la economía real de esta potencia mundial. Esto provocó la reducción del consumo y la inversión, el desequilibrio del comercio internacional, la pérdida de expectativas de crecimiento y la pérdida de la confianza de los consumidores. Como lo afirma Francisco Rojas Aravena (2009), en el $5^{\circ}$ informe del secretario general de la Facultad Latino Americana de Ciencias Sociales (Flacso), titulado: Crisis financiera: construyendo una respuesta política latinoamericana, esta crisis no fue un fenómeno aislado, sino un desequilibrio en un contexto de diversas crisis globales, las cuales actualmente se han manifestado de distintas formas en todas las regiones del mundo, incluyendo la región de América Latina y el Caribe. El actual desequilibrio global no solo se manifiesta en los escenarios económicos, sino que también es evidente en la crisis alimentaria, la crisis energética, el cambio climático y las crisis políticas, que han perpetuado guerras y desatado nuevos conflictos en diferentes regiones como en los países del Medio Oriente, África e incluso Colombia, y su histórico conflicto interno de hace más de cinco décadas. El calentamiento global, el peligro de extinción de muchas especies entre ellas la humana, junto con la desigualdad y la violencia - estas últimas, que son vulneraciones a los derechos humanos - son solo parte de esta realidad que es indispensable superar.

Es en este contexto, donde las instituciones encargadas de generar el conocimiento, relacionadas con la educación, la investigación y el desarrollo, encuentran su verdadera razón de ser y la forma en que estas pueden aportar a superar dichos desequilibrios, que afectan a la población y sus territorios a nivel local y global. Comprometida con esta realidad, la Universidad Católica de Colombia, fundamentada en sus principios de contribuir en "la enseñanza de la verdad y de las ciencias al servicio del hombre y de los intereses de la comunidad", en el segundo semestre del año 2007, entre muchos de sus proyectos, presentó a la comunidad científica la Revista Finanzas y Política Económica, como alternativa y aporte para la superación de dichas problemáticas. Este proyecto editorial de divulgación científica ha sido liderado desde la Facultad de Economía, la cual, desde ese entonces, venía encaminando sus esfuerzos hacia el fortalecimiento de su capacidad investigativa, particularmente en los campos de la política económica, las finanzas y la economía social. Sin embargo, es hasta diciembre del 2009 que se publica el segundo número de la revista, resurgiendo así y convirtiéndose en complemento a otras propuestas editoriales nacionales e internacionales que divulgan los avances investigativos, relacionados con las ciencias económicas. Desde su origen hasta el año 2012, fueron editados ocho números en cuatro volúmenes, cumpliendo así, con cuatro años de existencia, en los cuales, los documentos publicados han sido dispuestos al servicio de la humanidad, la ciencia y el desarrollo. 
Por esto, en el presente número, hemos querido reconocer el esfuerzo histórico de la Facultad de Economía, de la Universidad Católica de Colombia, de los diferentes directores y editores, de los integrantes de los comités editorial y científico, de los pares evaluadores (revisores) y de los autores, de todos los números editados de esta revista, quienes con su profesionalismo, colaboración y confianza han permitido consolidar este espacio científico de construcción académica y desarrollo integral.

La presente edición, que da inicio al quinto año de existencia de la revista, marca una nueva etapa de esta publicación, caracterizada en el aumento de su visibilidad internacional por medio de diferentes sistemas de información y resumen (SIRes), de bases de datos bibliográficas con comité de selección (BBCS) y de algunos directorios bibliográficos de carácter nacional e internacional, entre las cuales encontramos a: EconLIT, REPEC y Ulrich Periodicals Directory, de Estados Unidos de Norte América; E-Revistas y Dialnet, de España; Latindex y CLASE, de México; el Directory of Open Access Journals (DOAJ), de Suecia; el Directory of Research Journal Indexing (DRJI), de India; Publindex y Dotec, de Colombia, y Actualidad Ibero Americana, de Chile.

En esta etapa, además de seguir con los objetivos, tanto de mejorar la calidad científica y editorial de la revista como de aumentar su visibilidad, también nos hemos propuesto, garantizar un impacto de calidad con esta publicación, el cual esperamos se refleje en los nuevos avances científicos que desde este espacio se puedan inspirar para todas las comunidades investigativas y académicas encargadas de generar los procesos y soportes para tomar las decisiones económicas y políticas más acertadas y convenientes de acuerdo a las necesidades del mundo actual.

En este sentido, presentamos a nuestros lectores la edición volumen 5, número 1 del año 2013 de la Revista Finanzas y Política Económica. Para dar inicio a este número Leonardo Vera, Dorelia Osorio y Albany Hernández, de la Universidad Central de Venezuela y Asociación Bancaria de Venezuela, muestran una evidencia empírica para la economía venezolana (entre los años 1970 y 2009) de la posible relación que existe entre el acceso y uso de los servicios financieros por parte de la población y el grado de desarrollo humano. Usando varias proxis de bancarización, encuentran que una mayor red de servicios y cobertura de depositantes explica las mejoras reportadas en el índice de desarrollo humano (IDH), y cómo este índice también es impactado positivamente por la evolución que ha tomado el precio real de los hidrocarburos petroleros y el gasto público por habitante. De esta manera, presentan una alternativa a la mirada de la relación entre el desarrollo financiero y el crecimiento económico, cuyo fin son las ganancias y la eficiencia, para concentrarse más bien en la importancia que tiene la masificación de los servicios financieros en el bienestar de la población.

El segundo documento, de autoría de Eliasib Naher Rivera Aya de la Universidad Jorge Tadeo Lozano de Colombia, presenta una reflexión de cómo en el marco de una propuesta de reforma a la educación superior, surgen tensiones respecto a temas como la autonomía, la financiación, la calidad, la educación superior y los sentidos de la universidad. Se muestra la educación superior como mercancía, lo cual representa una interpretación equivocada de este bien público que se encuentra al servicio de la sociedad. El documento caracteriza algunas tensiones respecto de los 
sentidos de la universidad, a partir del reconocimiento de las visiones antagónicas y los paradigmas que están detrás de dichas visiones, defendiendo la necesidad de mantener a la universidad alejada del ideal de la maximización de la rentabilidad financiera.

El tercer artículo es una revisión elaborada por Arturo Robles Valencia y Luis Huesca Reynoso del Centro de Investigación en Alimentación y Desarrollo de Sonora, México, la cual reseña la literatura teórica y empírica en relación a la incidencia fiscal y la posibilidad de generar una situación de mayor recaudación, con un trato justo de los contribuyentes por el sistema fiscal, desde el principio de la equidad horizontal y con miras a mejorar el estado de bienestar de la población, acorde a un efecto redistributivo. Los autores consideran la necesidad de una recaudación eficiente para generar un sistema robusto, el cual pueda solventar el gasto público para el caso mexicano, finalmente concluyen con una serie de comentarios acerca de la experiencia y la situación actual de la incidencia fiscal en México.

En el cuarto trabajo, Álvaro Fernando Narváez Rubiano de la Universidad del Valle, Colombia estudia los impactos de un cambio institucional, como la reforma laboral del 2002, sobre la demanda laboral colombiana, con base en datos panel suministrados por la Encuesta Anual Manufacturera desagregada a cuatro dígitos CIUU para el periodo 2001-2006. Además, de acuerdo con los planteamientos de Hamermesh (1993), estima elasticidades y los resultados del ejercicio econométrico, corroborando un elemento común de los trabajos empíricos, según el cual las elasticidades precios de los factores son mayores en el largo plazo. Igualmente, muestra como en el corto plazo la reforma tiene efectos negativos sobre la creación de empleos, mientras que en el largo plazo la reforma no tiene efectos sobre la demanda laboral manufacturera.

En quinto lugar encontramos a Nancy Paola Hernández y María del Pilar Sánchez Muñoz Clavijo de la Universidad de la Salle de Colombia, quienes presentan los resultados de una investigación que recolectó y sistematizó la información de las fichas Sirbe, historia sociofamiliar, terapia ocupacional, nutrición, y de la entrevista semiestructurada aplicada. Estas herramientas contribuyen a describir e interpretar, desde el enfoque de capacidades de Nussbaum, la realidad socioeconómica particular de la población beneficiaria del programa Centro AMAR en la localidad de San Cristóbal, entre 2007 y 2009. Las autoras identifican aspectos como la falta de continuidad y acompañamiento en los procesos de los niños, niñas y adolescentes, el desinterés de los cuidadores para cambiar sus hábitos de crianza y una leve mejoría en la calidad de vida de las familias, realidades que representan un reto para la construcción e implementación de políticas públicas encaminadas a fomentar el capital humano, consolidar el entorno familiar y contribuir al bienestar.

El sexto artículo, presentado por Diana Marcela Escandón Barbosa, Carlos Alberto Castillo López y Andrea Hurtado Ayala de la Universidad Javeriana de Cali y la Universidad del Valle, es una investigación sobre las condiciones principales del mercado exportador de las empresas born global en el caso colombiano. En este estudio se tiene en cuenta los principales factores del entorno que determinan su dinámica exportadora y el uso de la base de datos GEM Colombia del año 2011 Mediante un análisis descriptivo y la estimación de un modelo de conglomerados bietápico, se estudian 
297 empresas born global colombianas. Los resultados muestran que los cambios tecnológicos, las características sectoriales y la intensidad competitiva son factores determinantes de la dinámica exportadora de este tipo de empresas en Colombia. Por último se concluye que los empresarios se adaptan al mercado internacional con el mejoramiento continúo de sus productos y procesos.

Finalmente, Nury Yesenia Benítez Ibagué de la Universidad Nacional de Colombia, describe cómo las regalías se encuentran entre los recursos más importantes con que cuenta el Estado colombiano para jalonar el desarrollo y competitividad territorial. Asimismo, anota cómo las regalías vienen siendo ejecutadas de manera desigual e ineficiente. Muestra cómo el Gobierno nacional, a partir de la propuesta del Acto Legislativo 005 de 2011, ha expedido una serie de normas que cambian radicalmente su distribución, así como la forma de acceso y ejecución de dichos recursos. El documento realiza una exploración histórica del anterior régimen y el nuevo sistema, caracterizando el Sistema General de Regalías y estudiando su efecto fiscal sobre los municipios de sexta categoría del departamento de Boyacá.

Joan Miguel Tejedor Estupiñán

Editor 


\section{Editorial}

\section{On the anniversary of the Revista Finanzas y Política Económica}

In 2007 the world economic crisis became evident through the U.S. mortgage market downfall in the financial sector. The following year the crisis revealed its first consequences with the collapse of investments, which would have a direct adverse effect on the real economy of this world power. This caused a decrease in consumption and investment, an international trade unbalance, poor growth prospects and of consumers' confidence. As Francisco Rojas Aravena (2009) stated in the Secretary General Fifth Report of the Latin-American Social Science Faculty (Flacso), entitled Financial Crisis: building a political Latin-American response, this crisis was not an isolated event, but an unbalance in the context of several global crises which have currently become manifest in different ways all over the world, including Latin America and the Caribbean. The present-time world unbalance is not only evident in the economic scenario, but also in food crisis, energy crisis, climate change and political crises that have perpetuated wars and created new conflicts in different regions, as has happened in the Middle East, Africa and even in Colombia where the internal conflict is now five decades long. Global warming, endangered species including human beings, inequity and violence (which are human rights violations) are only parts of a reality we must overcome.

That is the context in which institutions that are meant to create knowledge concerned with education, research and development find their raison d'être and their way to contribute to overcome unbalances that affect people and their territories at local and global scale. The Universidad Católica de Colombia is committed to reality from its foundations and principles of contributing to "teaching truth and science at the service of humanity and the interests of the community". Therefore, in the second semester of 2007, among its many projects, the University presented to the scientific community the Revista Finanzas y Política Económica (Finance and Political Economy Journal) as an alternative and a contribution to overcome the situation. The Faculty of Economics leads this popularization of science editorial project. It had previously orientated its efforts to strengthen its research capability particularly in political economy, finance and social economy. Eight numbers in four volumes were issued from its beginning to 2012, celebrating 4 years of existence, time through which the published documents have been put at the service of humanity, science and development.

That is why we have decided to acknowledge in the current number the landmark efforts of the Faculty of Economics, the Universidad Católica de Colombia, all directors and editors, editorial and scientific board members and referees and authors of all the edited numbers of this journal who thanks to their professionalism, collaboration and trust have made possible and solid this scientific space of academic construction and integral development.

With this edition we initiate the fifth year of the journal. It sets a new phase for the publication, distinguished by a larger international visibility by means of several indexation systems, bibliographic databases with selection scientific committee, and some national and international bibliographic directories such as EconLIT, REPEC and Ulrich Periodical Directory from the US; E-Revistas and Dialnet, from Spain; Latindex and CLASE, from Mexico; the Directory of Open Access Journals (DOAJ), from 
Switzerland; the Directory of Research Journal Indexing (DRJI), from India; Publindex and Dotec, from Colombia and Actualidad Ibero Americana, from Chile.

Along with keeping on with our purpose of improving the scientific and editorial quality of the journal and increasing its visibility, we are also set out to ensure a quality impact. We expect this impact to be reflected on new scientific progress on the part of academic and research communities responsible for generating processes and bases for proper and better political and economic decisions according to the needs of the current world.

To this effect, we present our readers with the Revista Finanzas y Política Económica, volume 5, number 1 issue of 2013. To open this edition, Leonardo Vera, Dorelia Osorio and Albany Hernández, from the Universidad Central de Venezuela and the Venezuelan Banking Association (Asociación Bancaria de Venezuela) present empirical evidence for Venezuelan economy (between 1970 and 2009) regarding a possible relation between how people access and use financing services and human development level. Using several proxies for access to banking services, the study finds robust results that indicate that a larger net of services and coverage of depositors explains reported improvements in Human Development Index (HDI). The evolutions of the real price of petroleum hydrocarbon and of the government expenditure per capita have had a positive impact on HDI. Thus, the analysis drifts apart from the well known, but controversial, connection between financial development and economic growth which is based on efficiency profits and it rather concentrates on the importance that financing services massification has on people's welfare.

The second article by Eliasib Naher River Aya from Universidad Jorge Tadeo Lozano, Colombia, makes a reflection on how tensions arise in the context of a higher education reform proposal around such issues as autonomy, financing, quality, higher education and the sense and meaning of University. Higher education is portrayed as merchandise, which certainly is a misinterpretation of this public good at the service of society. The document describes some of those tensions regarding the senses and meanings of University based on the acknowledgement of the opposing visions and the paradigms behind them, and defends the need to keep University away from the search of maximizing financial profitability.

The third article is a review carried out by Arturo Robles Valencia and Luis Huesca Reynoso from the Food and Development Research Center (Centro de Investigación en Alimentación y Desarrollo) in Sonora, México. This paper reviews the theoretical and empirical literature concerning fiscal incidence and the possibility of generating a situation in which tax collection is increased on the basis of fair treatment for taxpayers on the part of the tax system. It all should be carried out from the principle of horizontal equity and with the intention of improving the welfare level of the population according to a redistributive effect. The authors consider the need of an effective tax collection to produce a robust system that is able to settle Mexican government expenditure. They finally conclude with a series of comments based on experience and on the current situation of fiscal incidence in Mexico.

In the fourth paper, Álvaro Fernando Narváez Rubiano, from the Universidad Central de Colombia, studies the impacts of an institutional change, such as the 2002 labor reform, on Colombian labor demand on the basis of panel data provided by the Annual Manufacturing Survey disaggregated at 
the 4-digit level of ISIC (International Standard Industrial Classification of all Economic Activities) for 2001-2006 and according to Hamermesh's (1993) theoretical formulations. It estimates elasticities and the econometric exercise confirms the element shared by all empirical studies, which is that long run price elasticity of the factors is larger than short run price elasticity It also shows how the reform has adverse effects on job creation on the short run, while on the long run it has no effects at all on the manufacturing labor demand.

The authors of the fifth article are Nancy Paola Hernández and María del Pilar Sánchez Muñoz Clavijo, from the Universidad de La Salle, Colombia. They present the results of a research that collected and systematized the information contained in the Sirbe filling cards (Sirbe is the acronym in Spanish for Sistema de Información para el Registro de Beneficiarios which means Beneficiary Registration Information System), regarding socio-familial history, occupational therapy, nutrition and in the information obtained through the semi-structured interview that was applied. These tools contribute to the description and interpretation, from Nusbaum's capabilities approach, of the particular socioeconomic reality of the AMAR Center recipient population in San Cristóbal, Bogotá, between 2007 and 2009. The authors identified the lack of continuity and accompaniment in the processes for children and teenagers, the lack of interest of caretakers in changing their raising habits and a slight improvement in the quality of life of the families. This represents a challenge in designing and implementing public policies that lead to promote human capital, strengthen family environment and generate elements that contribute to wellbeing.

The sixth article, presented by Diana Marcela Escandón Barbosa, Carlos Alberto Castillo López y Andrea Hurtado Ayala from Universidad Javeriana de Cali and Universidad del Valle, is a research about the main conditions of the export market for born global companies in Colombia. The study considers the factors in the context that primarily determine their export dynamics and uses the GEM Colombia 2011 database. By means of a descriptive analysis and the estimation of a two-stage cluster model it studies 297 Colombian born global firms. Results show that technological changes, sectorial characteristics and competitive intensity are factors that determine the export dynamics of born global companies in Colombia. The paper finally concludes that entrepreneurs adapt to the international market by constantly improving their products and processes.

Finally, Nuri Yesenia Benitez Ibagué, from Universidad Nacional de Colombia describes how royalties are one of the most important resources Colombian government has to propel territorial development and competitiveness. She also comments on how the have been inequitably and inefficiently paid. Nuri shows how after the Legislative Act 005 from 2011 was proposed the Government has issued a series of regulations that radically change their distribution and they ways are accessed and paid. The document undertakes a historical exploration of the previous regime and the new system in order to typify the Royalties General System and to analyze its fiscal effect on the six-class municipalities in the department of Boyacá.

Joan Miguel Tejedor Estupiñán Editor 


\section{Editorial}

\section{Em razão do aniversário da Journal Finanças e Política Econômica}

Em 2007, a crise econômica mundial se evidenciava na queda do mercado hipotecário do setor financeiro nos Estados Unidos da América; no ano seguinte, esta manifestava suas primeiras consequências com a queda dos investimentos, os quais afetariam diretamente a economia real dessa potência mundial. Isso provocou a redução do consumo e do investimento, o desequilíbrio do comércio internacional, a perda de expectativas de crescimento e a perda da confiança dos consumidores. Como o afirma Francisco Rojas Aravena (2009), no V relatório do secretário-geral da Faculdade Latino-americana de Ciências Sociais (Flacso), intitulado Crisis financiera: construyendo una respuesta política latino-americana (Crise financeira: construindo uma resposta política latino-americana), esta crise não foi um fenômeno isolado, e sim um desequilíbrio em um contexto de diversas crises globais, as quais atualmente vêm se manifestando de diferentes formas em todas as regiões do mundo, o que inclui a América Latina e o Caribe. O atual desequilíbrio global não somente se manifesta nos cenários econômicos, mas também é evidente na crise alimentar, na crise energética, na mudança climática e nas crises políticas que têm perpetuado guerras e desatado novos conflitos em diferentes regiões como nos países do Oriente Médio, da África e, inclusive, na Colômbia, e seu histórico conflito interno de mais de cinco décadas. $\mathrm{O}$ aquecimento global, o perigo de extinção de muitas espécies, entre elas a humana, junto com a desigualdade e a violência -estas últimas, que são vulnerações aos direitos humanos- são somente parte desta realidade que é indispensável superar.

Nesse contexto, no qual as instituições encarregadas de gerar o conhecimento, relacionadas com a educação, pesquisa e desenvolvimento, encontram sua verdadeira razão de ser e a forma em que estas podem contribuir para a superação desses desiquilíbrios, que afetam a população e seus territórios no âmbito local e global. Comprometida com esta realidade, a Universidade Católica da Colômbia, fundamentada em seus princípios de contribuir no "ensino da verdade e das ciências ao serviço do homem e dos interesses da comunidade", no segundo semestre de 2007, entre muitos de seus projetos, apresentou à comunidade científica a Journal Finanças e Política Econômica, como alternativa e contribuição para a superação dessas problemáticas. A Faculdade de Economia tem liderado esse projeto editorial de divulgação científica desde então e vem encaminhando seus esforços ao fortalecimento de sua capacidade investigativa, particularmente nos campos da política econômica, das finanças e da economia social. Contudo, é somente em dezembro de 2009 que se publica o segundo número da Revista, ressurgindo assim e convertendo-se em complemento de outras propostas editoriais nacionais e internacionais que divulgam os avanços investigativos relacionados com as ciências econômicas. Desde sua origem até 2012 , foram editados oito números em quatro volumes, cumprindo assim com quatro anos de existência, nos quais os documentos publicados foram dispostos ao serviço da humanidade, da ciência e do desenvolvimento. 
Por isso, no presente número, queremos reconhecer o esforço histórico da Faculdade de Economia, da Universidade Católica da Colômbia, dos diferentes diretores e editores, dos integrantes dos comitês editorial e científico, dos pares avaliadores (revisores) e dos autores, de todos os números editados desta Revista, os quais, com seu profissionalismo, colaboração e confiança, vêm permitindo consolidar este espaço científico de construção acadêmica e desenvolvimento integral.

A presente edição, que dá início ao quinto ano de existência da Revista, marca uma nova etapa desta publicação, caracterizada no aumento de sua visibilidade internacional por meio de diferentes sistemas de informação e resumo (SIRes), de bases de dados bibliográficos com comitê de seleção (BBCS) e de alguns diretórios bibliográficos de caráter nacional e internacional, entre os quais encontramos: EconLIT, REPEC e Ulrich Periodicals Directory, dos Estados Unidos da América; E-Revistas e Dialnet, da Espanha; Latindex e CLASE, do México; Directory of Open Access Journals (DOAJ), da Suécia; Directory of Research Journal Indexing (DRJ), da Índia; Publindex e Dotec, da Colômbia, e Actualidad Ibero Americana, do Chile.

Nesta etapa, além de continuar com os objetivos, tanto de melhorar a qualidade científica e editorial da Revista quanto de aumentar sua visibilidade, também propomos garantir um impacto de qualidade com esta publicação, o qual esperamos que se reflita nos novos avanços científicos que deste espaço se possam inspirar para todas as comunidades investigativas e acadêmicas encarregadas de gerar os processos e suportes para tomar as decisões econômicas e políticas mais acertadas e convenientes de acordo com as necessidades do mundo atual.

Nesse sentido, apresentamos a nossos leitores a edição volume 5, número 1, do ano 2013, da Journal Finanças e Política Econômica. Para dar início a este número, Leonardo Vera, Dorelia Osorio e Albany Hernández, da Universidade Central da Venezuela e Associação Bancária da Venezuela, mostram uma evidência empírica para a economia venezuelana (entre 1970 e 2009) da possível relação que existe entre o acesso e o uso dos serviços financeiros por parte da população e o grau de desenvolvimento humano. Ao usar várias proxies de bancarização, constatam que uma maior rede de serviços e cobertura de depositantes explica as melhorias relatadas no índice de desenvolvimento humano (IDH), e como esse índice também é impactado positivamente pela evolução que vem tomando o preço real dos hidrocarbonetos petroleiros e o gasto público por habitante. Dessa maneira, apresentam uma alternativa para a relação entre o desenvolvimento financeiro e o crescimento econômico, cujo objetivo são os lucros e a eficiência para se concentrar mais na importância que tem a massificação dos serviços financeiros no bem-estar da população.

O segundo documento, de autoria de Eliasib Naher Rivera Aya, da Universidade Jorge Tadeo Lozano da Colômbia, apresenta uma reflexão de como, no marco de uma proposta de reforma da educação superior, surgem tensões a respeito de temas como a autonomia, o financiamento, a qualidade, a educação superior e os sentidos da universidade. Mostra-se a educação superior como mercadoria, o que representa uma interpretação errônea desse bem público que se encontra a serviço da sociedade. $O$ documento caracteriza algumas tensões com relação aos sentidos da universidade a partir do reconhecimento das visões antagônicas e dos paradigmas que estão por detrás dessas visões, defendendo a necessidade de manter a universidade afastada do ideal da maximização da rentabilidade financeira. 
O terceiro artigo é uma revisão elaborada por Arturo Robles Valencia e Luis Huesca Reynoso, do Centro de Pesquisa em Alimentação e Desenvolvimento de Sonora, México, a qual resenha a literatura teórica e empírica com relação à incidência fiscal e à possibilidade de gerar uma situação de maior arrecadação, com um tratamento justo dos contribuintes pelo sistema fiscal a partir do princípio de equidade horizontal e visando melhorar o estado de bem-estar da população, de acordo com um efeito redistributivo. Os autores consideram a necessidade de uma arrecadação eficiente para gerar um sistema forte, o qual possa solucionar o gasto público para o caso mexicano. Finalmente concluem com uma série de comentários sobre a experiência e a situação atual da incidência fiscal no México.

No quarto trabalho, Álvaro Fernando Narváez Rubiano, da Universidade Central da Colômbia, estuda os impactos de uma mudança institucional, como a reforma laboral de 2002, sobre a demanda laboral colombiana, com base em dados em painel fornecidos pela Pesquisa Anual Manufatureira separada em quatro dígitos CIUU para o período 2001-2006. Além disso, conforme proposições de Hamermesh (1993), estima elasticidades e os resultados do exercício econométrico, corroborando um elemento comum dos trabalhos empíricos, segundo o qual as elasticidades preços dos fatores são maiores a longo prazo. Além disso, mostra como a curto prazo a reforma tem efeitos negativos sobre a criação de empregos, enquanto a longo prazo a reforma não tem efeitos sobre a demanda manufatureira.

Em quinto lugar Nancy Paola Hernández e María del Pilar Sánchez Muñoz Clavijo, da Universidade de La Salle da Colômbia, apresentam os resultados de uma pesquisa que coletou e sistematizou a informação das fichas Sirbe, história sociofamiliar, terapia ocupacional, nutrição e da entrevista semiestruturada aplicável. Essas ferramentas contribuem para a descrição e interpretação, a partir do enfoque de capacidades de Nussbaum, a realidade socioeconômica particular da população beneficiária do programa Centro AMAR, na região de San Cristóbal, entre 2007 e 2009. As autoras identificam aspectos como a falta de continuidade e acompanhamento nos processos das crianças e adolescentes, o desinteresse dos cuidadores para mudar seus hábitos de criação e uma leve melhoria na qualidade de vida das famílias, realidades que representam um desafio para a construção e implementação de políticas públicas dirigidas à fomentação do capital humano, à consolidação do contexto familiar e à contribuição para o bem-estar.

O sexto artigo, apresentado por Diana Marcela Escandón Barbosa, Carlos Alberto Castillo López e Andrea Hurtado Ayala, da Universidade Javeriana de Cali e da Universidade del Valle, é uma pesquisa sobre as condições principais do mercado exportador das empresas born global no caso colombiano. Neste estudo, consideram-se os principais fatores do contexto que determinam sua dinâmica exportadora e o uso da base de dados GEM Colômbia de 2011. Por meio de uma análise descritiva e de uma estimativa de um modelo de conglomerados two-stage, estudam-se 297 empresas born global colombianas. Os resultados mostram que as mudanças tecnológicas, as características setoriais e a intensidade competitiva são fatores determinantes da dinâmica exportadora desse tipo de empresas na Colômbia. Por último, conclui-se que os empresários se adaptam ao mercado internacional com o melhoramento contínuo de seus produtos e processos. 
Finalmente, Nuri Yesenia Benítez Ibagué, da Universidade Nacional da Colômbia, descreve como as regalias se encontram entre os recursos mais importantes com que o Estado colombiano conta para impulsionar o desenvolvimento e competitividade territorial. Além disso, observa como as regalias vêm sendo executadas de maneira desigual e ineficiente. Mostra como o Governo nacional, a partir da proposta do Ato Legislativo 5 de 2011 expediu uma série de normas que mudam radicalmente sua distribuição, assim como a forma de acesso e execução desses recursos. O documento realiza uma exploração histórica do anterior regime e do novo sistema, caracterizando o Sistema Geral de Regalias e estudando seu efeito fiscal sobre os municípios de sexta categoria do estado de Boyacá.

Joan Miguel Tejedor Estupiñán

Editor 
